\title{
Analysis of Land Secondary Market in Kunming
}

\author{
Jiang Rui ${ }^{1}$, Zhang Zhenwen ${ }^{2 *}$, Li Leilei ${ }^{3}$ \\ 1. School of Economics, Yunnan University of Finance and Economics, Kunming, China \\ 2,3. Kunming Institute of land planning and surveying and mapping, Kunming, China \\ 1.jiangrui0420@163.com;2.1836553146@qq.com;3.2944402209@qq.com
}

\begin{abstract}
The active trading of land secondary market in Kunming has played an important role in the economic and social development. However, the problems of unsound trading rules and incomplete supervision have been continuously highlighted. Based on the statistical data of mortgaged land, transferred land, and supplied land of Kunming City from 2014 to 2016, this paper analyzes the trading entities, distribution areas, types of use rights, land use of the land secondary market, and compares them with the primary market of the land. The results will provide reference for the formulation of trading rules for the secondary market in Kunming City and other regions.
\end{abstract}

Keywords-land secondary market, mortgaged land, transferred land, Kunming City

Land secondary market is an important part of China's urban and rural unified construction land market. It plays a positive role in promoting the optimal allocation of land resources and saving in intensive use. However, problems such as unsound trading rules, asymmetric transaction information, and incomplete supervision are constantly highlighted.

The land secondary market has lots of transactions and high amounts in Kunming. It has played an important role in

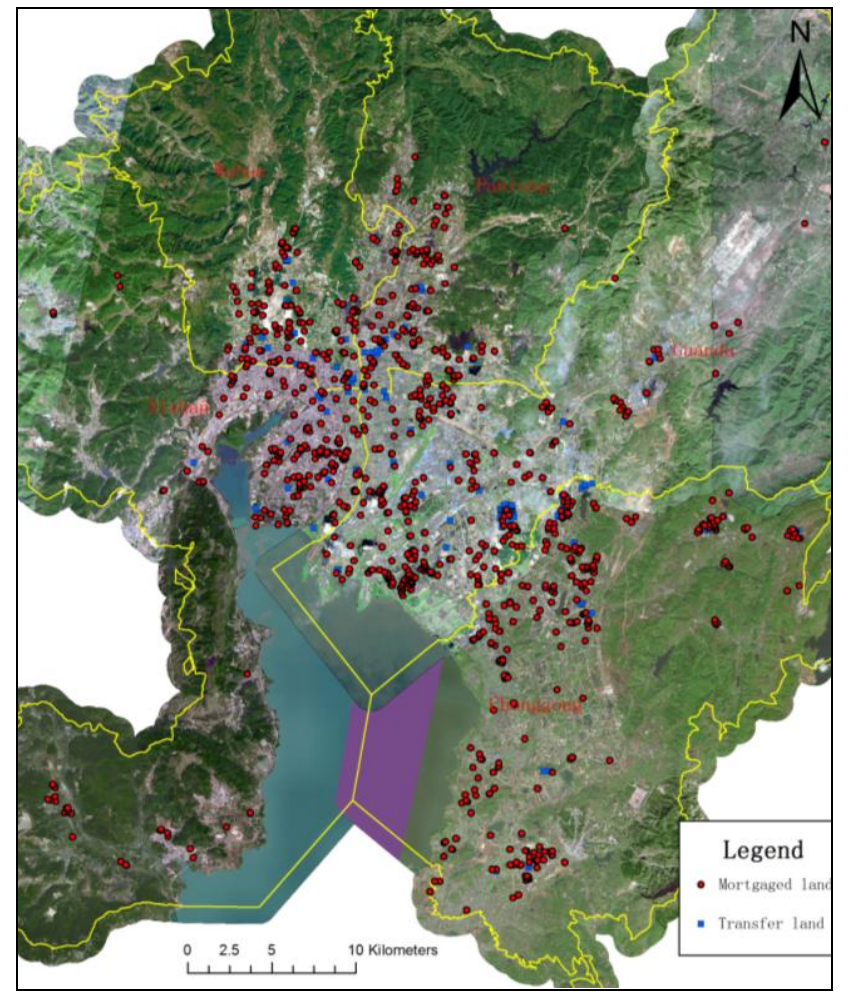

Figure 1 Distribution of Mortgage and Transfered land in Kunming( 2014-2016) economic and social development. Some problems have occurred frequently and have affected the returns of the national and local governments. Such as the planning use of land is inconsistent with the real use, and there are widespread stealth transactions. In particular, the supervision of allocated land is inadequate.

At present, the research on China's secondary land market mainly focuses on the analysis of status and problem of land secondary market.( Lu, Zhen and Liu, Wei and Song $2015,2017,2018)$ ) In order to fully understand the structure of the secondary land market in Kunming City, this paper mainly analyzes the market players, region, use, type of use right of the land secondary market and compares them with the primary market of the land.

\section{OVERVIEW OF LAND SECONDARY MARKET IN KUNMING}

The research area of this paper is the built-up area of Wuhua, Panlong, Xishan, Guandu and Chenggong districts in Kunming City. Data of mortgaged land, transferred land, and supplied land from 2014 to 2016 were collected from the land and resources department. Due to the lack of statistical data on leased land, this article only analyzes the mortgage and transferred land in Kunming.

From 2014 to 2016, there were 1,064 mortgaged lands, with a mortgage area of 4,800 hectares, and a mortgage amount of 145,823 million yuan in Kunming. A total of 226 lands were transferred, the transfer area was 350 hectares, and the transfer amount was 8.965 billion yuan.

\section{ANALYSIS OF MARKET BODY}

\section{A. Demand analysis}

Demands for mortgaged land are mainly banks and financial institutions. In the past three years, the demand for mortgaged land was mainly from state-owned banks, joint-stock commercial banks, city commercial banks, rural credit cooperatives and non-bank financial machines in Kunming.

Loan policies of state-owned banks generally are strict, but interest rates are relatively low. Loan policies of commercial banks are relatively flexible and they provide faster lending, but generally have higher interest rates. The demand of mortgaged land was mainly state-owned banks, joint-stock commercial banks, and city commercial banks from 2014 to 2016 in Kunming. Their proportion of mortgage amount, mortgage area, and mortgage amount were between $64 \%$ and $68 \%$.Non-bank financial institutions have become a major source of loans due to their flexibility in lending and convenient procedures, and the proportion of mortgage area and mortgage amount has been maintained at a high level.

Demands of the transferred land include private enterprises and state-owned enterprises. Transfer area and transfer amount proportion of private companies and state-owned enterprises were more than $98 \%$. The demand of 
personal was less than $1 \%$. In 2015 , there was a land that was divided and transferred to 32 assignees. The average transferee area was about 339 square meters. Land division transfer will be the main trend in future, and it is necessary to strengthen the active guidance of enterprises and individuals.

\section{B. Supplier analysis}

The suppliers of mortgaged land are mainly private companies. The proportions of mortgage area and mortgage amount exceeded $77 \%$, and show an increasing trend.

The suppliers of transferred land include private enterprises and state-owned enterprises, and the proportions of transfer area and transfer amount exceeded 97\%.Compared to the demanders, there was less personal land supply. Part of the land was divided and transferred to individuals by private enterprises.

\section{Regulator analysis}

The management of land secondary market in Kunming is mainly through the Ministry of Land and Resources and government departments to carry out coordinated management of the land market. Local governments in the land primary market are both the role of the supplied land and the managers of the primary and secondary land markets, making our country's land market distinct from the other countries' land markets. The content of land management in China is richer, and management is more complex and more difficult.

\section{DISTRIBUTION AREA ANALYSIS}

From the perspective of the distribution areas of mortgaged land, the mortgage area and mortgage amount in the five districts of Kunming City showed a decline. The land mortgage amount and area were the largest in Chenggong District, Panlong District was the smallest, and the mortgage amount was the largest in Guandu District and the smallest in Wuhua District. The Chenggong District was an area that Kunming City vigorously developed. The industrial land was mainly concentrated in Chenggong District. Industrial land generally had a large mortgage area, but the mortgage price was low. In Guandu District, the economic growth in recent years was faster than in the other four regions, and the mortgage amount was the largest.

From the perspective of the distribution areas of transferred land, the number of transferred land in Guandu District was the highest. The Chenggong District had the largest transfer area, exceeding 50\%. And Panlong District had the highest transfer amount. In general, although the transfer area of Chenggong District was the largest, the transfer unit price was lower, while the unit price of land transferred in Panlong District was high, and the total amount of transferred land was the highest in the five districts.

Researching from the transaction in each region, the secondary market land in Guandu District and Chenggong District was active, and industrial land was mainly concentrated in these two regions. There were also more commercial land and residential land in Guandu District, and more attention should be paid to activating land transactions in other regions.

\section{USAGE RIGHTS TYPE ANALYSIS}

The mortgaged land in Kunming City was mainly assigned land, and the proportion of allocated land was continuously decreasing. Before 2014, there was a certain amount of allocated land in the mortgaged land. Many allocated lands were changed to assigned land and land grant fees were paid. When these lands were mortgaged again, the proportion of the amount, area, and amount of assigned land will increase.

All the transferred lands were assigned land from 2014 to 2016 in Kunming.

\section{LAND USE ANALYSIS}

The mortgaged and transferred land was mainly industrial land, commercial land, and residential land. The proportion of mortgaged land area and amount of these three types were more than $97 \%$, and the transferred land area and amount were more than $83 \%$. There was also a small amount of land for transportation, public management and public services, agricultural land, etc. in mortgage and transferred land.

In the mortgaged land market, commercial land had the largest mortgage area, and the mortgage unit price was the highest. The proportion of mortgage amount more than half of the total. The mortgage unit price of industrial land was low. The proportion of mortgage area was about $29 \%$, and the proportion of mortgage amount was less than $6 \%$. In the transferred land market, the transferred land quantity of industrial land was the largest, but the transferred land amount was smallest. The transferred land area and amount of residential land were the highest.

In general, the mortgage market of commercial land was active, and the transfer market of industrial and residential land was active.

\section{COMPARATIVE ANALYSIS OF PRIMARY AND SECONDARY LAND MARKET}

The primary land market was the market of assigned and allocated land. The demander in the primary market was the supplier to the secondary market. The price and supply of the primary market determine the price and supply of the secondary market.

\section{A. Comparative analysis of the overview}

Comparing the area and amount of supplied land, mortgaged land and transferred land from 2014 to 2016 in Kunming City, it can be seen that the mortgaged land area and amount are both greater than the supplied land area and price, and transferred land was the lowest. The trend in the area and amount of mortgaged land and transferred land were consistent. The supplied land area was largest in 2015, but the price was lowest. In 2015, more allocated land for transportation was provided, and such land did not have to pay the land grant fee, and it could not enter the secondary market for land transactions.

\section{B. Comparative analysis of Distribution area}

The land supply was mainly concentrated in Guandu District and Chenggong District. The proportion of supply area of these two districts was $68 \%$, and the proportion of supply amount was $48 \%$.

Transactions in the Guandu District and Chenggong District were more active in the primary and secondary markets. The transaction amount was lower than residential and commercial land, due to the large number of industrial lands in these two regions. 


\section{Comparison analysis of usage rights types}

The types of use rights of supplied land, mortgaged land and transferred land were assigned land or allocated land.

The supply assigned land was reversed with a "V" pattern, and the allocation land was a positive "V" type from 2014 to 2016. When the allocated land area was large, the supply area of the assigned land was reduced. The allocated land price has been kept at a relatively low level. The proportion of the supply price in these three years was less than $9 \%$.

The area and amount of mortgage allocated land have been showing a downward trend. In the three years, the transferred land were the assigned land . It can be seen that the source of secondary land market was mainly the assigned land in the primary land market.

\section{Comparison analysis of Land use}

The supplied land uses mainly include industrial land, residential land, commercial land, public management and public service land, and transportation land. Land uses of the latter two are mainly allocated land, and most of them cannot enter the secondary land market. Mortgage and transferred land are mainly industrial land, residential land and commercial land.

In the supplied land market, the supply area and amount of residential land were the highest. In the mortgaged land market, the mortgage area and amount of commercial land were the highest. In the transferred land market, industrial and residential land transactions were most active.

\section{CONCLUSION}

\section{A. Conclusion of Mortgaged land analysis}

Mortgaged land demanders are mainly state-owned banks, joint-stock commercial banks, and city commercial banks. Suppliers are mainly private companies. In the distribution area, transactions in the secondary land market in Guandu District and Chenggong district were more active, but the mortgage area and amount in the five districts declined.

The type of mortgaged land use rights was mainly the assigned land, and the proportion of allocated land is continuously decreasing.

Mortgaged land mainly consists of industrial land, commercial land and residential land. The proportion of the land area and amount of these three types were more than 97\%. Mortgage commercial land had the largest area and amount, and industrial land had the smallest mortgage amount.

\section{B. Conclusion of Transferred land analysis}

The demanders and suppliers of transferred land were mainly private and state-owned enterprises. Land division and transfer will be the main trend of future transferred land methods.

In the distribution area, although Chenggong District had the largest transfer area, the transfer unit price was low and the transferred land amount was small. The unit price of the transferred land in Panlong District was high, and the transfer amount was the highest in the five districts.

Type of land use rights of transferred land were the assigned land.

Land use of transfer is mainly industrial land, commercial land and residential land. Residential and industrial land transactions were more active.

\section{Comparison with the primary land market}

Mortgaged land area and amount were greater than supplied land area and amount. The transaction area and amount in the primary and secondary land markets were concentrated in Guandu District and Chenggong District. Kunming Economic and Technological Development Zone and Kunming New City High-tech Industrial Base are located in Guandu District and Chenggong District, supplied land and transactions are more active. These two regions have more industrial land, and the transaction amount was lower than residential and commercial land. The types of use rights of supplied land, mortgaged land and transferred land are all assigned or allocated land. The area and amount of industrial land, residential land and commercial land traded in the primary and secondary land markets are relatively large.

In summary, the secondary land market is affected by the primary land market. The main distribution area, usage rights types, and use of transaction land of the secondary land market is basically the same as the primary land market, but it is more active than the primary land market.

\section{ACKNOWLEDGMENTS}

This work was supported by the National Natural Science Foundation of China Projects (NSFC) number 41562017.

\section{REFERENCES}

[1] Lu,W.M. (2015). Problems and Regulations in the Secondary Land Market in China [J]. Urban issues, 3:31-36. (in Chinese).

[2] Zhen J.P. \&Liu Z.Y. (2017). The Status of Secondary Land Market in Changsha City [J]. China Land, 7(17):51-53. (in Chinese).

[3] Wei L. \& Song J.N.(2018). Perfecting the System of Secondary Land Market in China[J]. China Land, 1(5):18-20. (in Chinese). 